\title{
Emotionally engaged or feeling anxious and cynical? School experiences and links to school achievement among Finland-Swedish general and special education students
}

\author{
Marina Palmgren ${ }^{1}$ (D) K Kirsi Pyhältö ${ }^{2,3,4} \cdot$ Janne Pietarinen $^{5} \cdot$ Jenni Sullanmaa $^{5,2}$. \\ Tiina Soini ${ }^{6}$
}

Received: 4 April 2020 / Accepted: 19 August 2021 / Published online: 25 September 2021

(c) The Author(s) 2021

\begin{abstract}
The aim of the study was to enhance understanding of how seventh graders vary in emotional engagement and experienced well-being at school in terms of anxiety and cynicism. The two profiles were explored, and comparisons were made between students in general education and those in special education. The study participants comprised 119 Finland-Swedish students from five secondary schools. Four emotional-engagement and well-being profiles were identified based on cluster analysis. The students with the most typical profile were moderately engaged in teacher-student interaction and emotionally highly engaged in peer interaction, combined with a low risk of anxiety and cynicism. The profiles showed no statistically significant differences regarding gender and school achievement. However, there were differences between students in special education and those in general education. In Finland, Swedish -speaking Finns are a language minority group. Swedish has official language status in Finland. Compared to many other language minority groups they can be considered somewhat exceptional, since according to many welfare indicators they tend to do better than the general population. There are a few studies on differences between Swedish and Finnish- speaking students' school experiences in Finland, however, so far studies exploring Swedish- speaking general and special education students' emotional engagement and study well-being in terms of anxiety and cynicism have been scarce.
\end{abstract}

Keywords Emotional engagement - School experiences - School achievement · Secondary school $\cdot$ General education students $\cdot$ Special education students

Marina Palmgren

marina.palmgren@helsinki.fi

Extended author information available on the last page of the article 


\section{Introduction}

Most children are eager to start school. Yet, on the global level it seems that satisfaction with school declines systematically over the years (PISA, Program for International Student Assessment, 2012), and this includes Finland (Wang et al., 2015). The implication is that, for some students, school does not offer an optimal environment in terms of emotional engagement. There is evidence that the quality of social relationships within school plays a central role in facilitating an emotionally engaging school experience (Skinner Belmont, 1993). Students who perceive themselves as members of the school community, for example, achieve higher grades, are more likely to complete their studies successfully (Finn, 1993; Finn \& Voelk1, 1993) and experience less study burnout (Salmela-Aro et al., 2009) than those who consider themselves outsiders. It has also been shown that a strong sense of belonging at school, student co-operation and teacher support relate to a positive school experience (PISA, Program for International Student Assessment, 2018). Peer relationships appear to play a crucial role in determining changes in school happiness (Uusitalo-Malmivaara, 2014).

It has been suggested that emotional engagement, referring to positive affects towards school, and perceived connectedness and support from teachers and peers in particular, is a key mediator for students in terms of effort, achievement and persistence in school work (Akiva et al., 2013; Appleton et al., 2006; Audas, \& Willms, 2001; Finn, 1993; Finn \& Rock, 1997; Fredricks et al., 2004; Furlong \& Christenson, 2008; Janosz et al., 2000; Lam et al., 2012; Seligman \& Csikszentmihalyi, 2000; Willms, 2003). There is also evidence that emotional engagement in school is related to experienced well-being among students (Salmela-Aro et al., 2011; Wang, Willett, \& Eccles, 2011), and may also buffer any negative factors coming from outside school. It could be assumed that the opportunity to engage emotionally in school is particularly significant for vulnerable students such as those in special education (Lappalainen et al., 2009; Reschly \& Christenson, 2006), for example, who may be less interested in doing so than their average-achieving peers as manifested in misbehaviour or coming unprepared to lessons (Reschly \& Christenson, 2006). Meaningful school experiences could help in terms of building an emotionally engaging learning environment for all, including students in special education (Caraway, Tucker, Reinke, \& Hall, 2003; Jindal-Snape \& Miller, 2008; Osterman, 2000).

However, little is known about what constitutes an emotionally engaging school experience in terms of peer and teacher-student relations (e.g., Fall \& Roberts, 2012; Pietarinen, Soini, \& Pyhältö, 2014; Skinner \& Belmont, 1993; Skinner et al., 2009; Wang \& Eccles, 2013) and how they relate to experienced school-related anxiety and cynicism (Wang, Eccles, Willett, \& Peck, 2011). Even less is known about individual variations in such experience, or about any differences between students in special education and those in general education, among the language minority groups in particular. Recent investigation explores the interrelations between emotional-engagement, i.e., a sense of belonging, in the teacher-student relationship and the peer group combined with perceived 
anxiety and cynicism among students at schools. Our analyses therefore focus on the emotional- engagement and well-being profiles of students, and on differences in the profiles of students in general education compared with special education among the Swedish-speaking language minority group in Finland. FinlandSwedish-speaking students provide a particularly interesting case for the study, since unlike many other of language minority groups (e.g., Cummins \& Swain, 2014; Loingsigh \& Mozzon-McPherson, 2020; Mady \& Muhling, 2017). they are not disadvantaged. They held strong official language status, having the right to study in their native language and exceeding levels of life satisfaction, e.g., social cohesion, longevity, and higher general well-being (Nyqvist et al., 2008) compared to their Finnish- speaking peers (Vincze \& Harwood, 2015). Yet, the Swedish-speaking student learning outcomes have been shown to be lower than the Finnish- speaking (PISA, Program for International Student Assessment, 2009). There are a few studies on differences between Swedish and Finnishspeaking students' school experiences in Finland (Korhonen, 2016). however, so far studies exploring Swedish-speaking general and special education students' emotional engagement and study well-being in terms of anxiety and cynicism have been scarce. Except for the welfare indicators, Finland has a strong historical background of being a part of Sweden. ${ }^{1}$

\section{Students' emotional engagement in school}

\subsection{Emotional engagement in the student-teacher relationship}

Findings from an extensive body of research on students' emotional engagement show that the quality of the teacher-student relationship has a significant impact on school achievement (Elffers, Oort, \& Karsten, 2012; Furrer, 2010; Hargreaves, 2000; Hughes, Im, \& Wehrly, 2014; King, 2015; Lee, 2012; Lichtenfield et al., 2012; McGrath \& Bergen, 2015; Oelsner, Lippold, \& Greenberg, 2010; Reschly \& Christenson, 2006; Salmela-Aro et al., 2011; Upadyaya \& Salmela-Aro, 2011; Virtanen, Lerkkanen, Poikkeus, \& Kuorelahti, 2014; Wu et al., 2010). In fact, teacher support has been suggested to be the strongest predictor for student engagement at school and school achievement (Lam et al., 2012). It has also been found that teacher support plays a particularly important role in enhancing academic efficacy among students in special education (Anderson et al., 2004; Finn \& Rock, 1997; Linnakylä \& Malin, 2008; Matzen et al., 2010; Pitt \& Curtin, 2004; Uusitalo-Malmivaara et al., 2012).

Those who have a warm and supportive relationship with their teacher, for instance, appear to be academically more successful (Baker et al., 2008; Lam

\footnotetext{
1 Throughout the history of Finland, Swedish has been spoken by a strong part of society and is still a crucial part of the country's identity. Finland still maintains two national languages, Finnish and Swedish. From Swedish in Finland. (2021, July). Helsinki: Folktinget, the Swedish Assembly of Finland. https://folktinget.fi/Site/Data1597/Files/Folktinget_SwedishInFinland_broschyr_A506.pdf.
} 
et al., 2012; Wu et al., 2010), to attain higher levels of academic self-efficacy and to engage in self-regulated learning activities more frequently (Ryan \& Patrick, 2001) than their less fortunate counterparts. Working in small groups and interactive instruction combined with individual support (Baker et al., 2008) and inclusive practices also seem to benefit these students in terms of generating positive school experiences (Matzen et al., 2010; Pitt \& Curtin, 2004; Uusitalo-Malmivaara et al., 2012). The extent to which students experience such support in teacher-student relationships may vary. Findings on gendered differences in emotional engagement, for instance, are contradictory. According to the results of some studies, student-teacher relationships influence school achievement more among girls than among boys (Lee, 2012), whereas other studies reveal no such evidence-although it has been reported that boys experience less teacher support than girls do (Lam et al., 2012).

It has further been reported that emotional engagement in the teacher-student relationship has a significant effect on the long-term social development of students (Battistich \& Hom, 1997; Bossaert et al., 2012; Caraway et al., 2003; Han, 2010; Langher, Ricci; Reversi, \& Citarelli, 2010; Samdal et al., 1999; Wang \& Holocombe, 2010), including lower levels of truancy (Virtanen, et al., 2014; Yunus, Osman, \& Ishak, 2011). Teacher support also appears to have a positive impact on students' relationships with their peers (e.g., Hughes; Im, \& Wehrly, 2014; McGrath \& Bergen, 2015; Nurmi, 2012; Thijs et al., 2012; Zee et al., 2013), enhancing how those in special education engage emotionally with their peers (Belfi et al., 2012; Matzen et al., 2010; Pitt \& Curtin, 2004). Moreover, cooperative goal setting in the classroom has been associated with both higher achievement and positive peer relationships among students (Roseth, Johnson, \& Johnson, 2008). Overall, these findings imply that experiencing teacher support, receiving encouraging feedback and being fairly treated by teachers are of importance to all students, but particularly to those in special education, since it has shown to be associated with the increased academic self-efficacy (Uusitalo-Malmivaara et al., 2012) and pro-social behaviors (Belfi et al., 2012), typically at stake due to their socio-emotional challenges or/ and learning disabilities (Matzen et al., 2010; Pijl, Skaalvik, \& Skaalvik, 2010; The Finnish National Board of Education, Helsinki, Finland 2016).

\subsection{Emotional engagement with peers}

The peer group becomes a more prominent developmental context during adolescence (Steinberg \& Morris, 2001). Students have a great need for peer relatedness, in other words a sense of belonging in a peer group and having emotional support from their peers (Furrer \& Skinner, 2003; Sulkowski, Demaray, \& Lazarus, 2012; Wang \& Eccles, 2013). This, in turn, is essential in facilitating emotionally engaging school experiences (Bendelow \& Mayall, 2002; Pedersen, Vitaro, Barke, \& Borge 2007; Rudolph et al., 2014; Pijl, Skaalvik, \& Skaalvik, 2010; Wang \& Eccles, 2013) and pursuing academic success (Oberle \& Schonert-Reichl, 2013; Roseth, et al., 2008; Zimmer-Gembeck et al., 2006). It has been shown that peer support and approval are especially important for students in special education (Lovitt et al., 1999; Palmgren, Pyhältö, Pietarinen, \& Soini, 2017; Bossaert et al., 2012; Langher, 
et al., 2010) and have a positive impact on learning outcomes. However, attracting such support calls for interaction skills combined with self-regulation (Milsom \& Glanville, 2010), which may well be challenging for these students (Filippello, Marino, Spadaro, \& Sorrenti, 2013; Sattoe, Hilberink, van Staa, \& Bal, 2014).

A weak sense of belonging and negative perceptions of school have been associated with destructive behaviours such as bullying (Harel-Fisch et al., 2011), truancy (Virtanen et al., 2014) and dropping out of school (Carbonaro, 2013). On the other hand, strong social ties among students seem to have a positive impact on school achievement and adjustment, especially among those in special education (Cappellla et al., 2013; Furrer, 2010). However, a sense of belonging in the peer group does not necessarily contribute to a positive school trajectory (Sattoe, et al., 2014) or to achievement at school (e.g., Chen et al., 2010; You, 2011; Wang et al., 2015). Indeed, the peer group may share negative attitude towards schoolwork and to school attendance via their peers but may not find studying engaging or enjoyable (Lawson \& Masyn, 2015; Linnakylä \& Malin, 2008).

School engagement seems to decrease over the middle school period, implying that measures to promote the school engagement should be taken earlier (Oelsner, 2010). This involves efforts to influence students' sense of belonging and peer support (Lam et al., 2012; Oelsner, 2010). In any case, maintaining functional peer relations and engaging effectively in academic tasks seem to generate social tension among students (e.g., Furrer, 2010; Ulmanen, Soini, Pietarinen, \& Pyhältö, 2016). Not only do functional teacher-student and peer relations appear to engage students effectively in academic tasks, but they also have the power to lessen school-related anxiety and cynicism (Denham et al., 2012; Hargreaves, 2000; Hart, 2014; King, 2015; Maslach \& Jackson, 1981; Midgley \& Edelin, 1998; Salmela-Aro et al., 2009; Stiglbauer et al., 2013).

\subsection{Emotional engagement and its connection to anxiety and cynicism in school}

Cynicism in the school context entails distant and negative attitudes towards school work and to school attendance in general, and towards studying, teaching and the teachers, and feeling inadequate as a student (Salmela-Aro et al., 2008, 2009). School-related anxiety, in turn, refers to negative activating emotions concerning school-related issues, such as exhaustion due to school demands, feelings of stress and being afraid of failing (Chen et al., 2010; Hart, 2014; Lichtenfeld et al., 2012; Salmela-Aro et al., 2008; Salmela-Aro et al., 2009; Sorrenti, Filippello, Orecchio, \& Buzzai, 2016; Tulis \& Fulmer, 2013). It has been shown that cynicism is associated with low achievement and an increased risk of dropping out of school (Adhiambo, Odwar \& Mildred, 2016; Finn \& Rock, 1997; SalmelaAro et al., 2008; Salmela-Aro et al., 2009; Korhonen, 2016; Virtanen et al., 2014; $\mathrm{Wu}$ et al., 2010). There is also research evidence indicating that students in special education, specifically those with learning disabilities, have an elevated risk of experiencing cynicism related to school (Korhonen et al., 2016; Salmela-Aro et al., 2009) and a higher tendency to become depressed than students without such disabilities (Maag \& Reid, 2006). Moreover, although in general, girls tend 
to be more emotionally engaged in school and have higher achievement than boys (Lam et al., 2012; Oelsner, 2010) they are also reported to be at a greater risk of suffering from cynicism than boys (Salmela-Aro et al., 2008).

Results related to school-related anxiety are less consistent, particularly in terms of achievement. Whereas some studies report that extensive anxiety is related to poorer grades (Salmela-Aro et al., 2009; Chen et al., 2010; Hart, 2014; PISA, Program for International Student Assessment, 2015), others indicate that experiencing some anxiety may be beneficial to achievement (Wang et al., 2015, Wang \& Peck, 2013; Linnakylä \& Malin, 2008; Tulis \& Fulmer, 2012. Schoolrelated anxiety among Finnish students is reported to have increased over the years (Wang et al., 2015). It has also been shown that such anxiety relates to social relationships with peers. Hence, better social relationships at school may reduce anxiety, which in turn may enhance learning motivation. (Magelinskaite, Kepalaite, \& Legkauskas, 2014). It would seem that both boys and girls suffer from school-related anxiety (Korhonen, 2016; Lichtenfield et al., 2012; SalmelaAro et al., 2008; Yuksel \& Geban, 2016).

Evidence on how the quality and quantity of social interaction with teachers and peers associates with successful studying is somewhat contradictory. It has been found that teacher support, in other words high-quality teacher-student involvement, decreases anxiety among students and enhances school achievement on the one hand (Tulis \& Fulmer, 2013), whereas other studies report no association between social connectedness and increased levels of well-being among students (Sattoe et al., 2014). Interestingly, students in special education studying in a special school have frequently reported experiences of social isolation and being emotionally insecure, whereas the experiences of these students attending regular school appear to be beneficial in terms of facilitating the learning of appropriate social skills (Belfi et al., 2012; Filippello et al., 2013; Pijl et al., 2010; and further promoting school achievement (Lawson \& Masyn, 2015; Sulkowski et al., 2012). Despite the somewhat contradictory evidence concerning the interrelation between social relationships and school-related anxiety and cynicism, overall the findings imply that the quality of social relationships within school plays a major role in giving students emotionally engaging school experiences (e.g., Skinner \& Belmont, 1993) in terms of both mediating their achievements and efforts (e.g., Akiva et al., 2013; Furlong \& Christenson, 2008) and promoting well-being (Salmela-Aro et al., 2009; Wang et al., 2015). Emotional engagement seems to be particularly challenging for students in special education (e.g., Lappalainen et al., 2009, Reschly \& Christenson, 2006). In sum, research findings indicate a strong need to enhance understanding of the student's sense of belonging in teacher-student and peer relations, and of the varying consequences for student well-being and adolescent development (Wang et al., 2015). It could be assumed that well-functioning social relationships with teachers and peers buffer school anxiety and cynicism towards studying among all students, but particularly among those in special education. Furthermore, special education students seem to need more support from teachers in their social skills to succeed in school and feel well and belonging a long run. 


\section{Method}

\subsection{The aim of the study}

The aim of the study was to explore individual variation among students in terms of emotionally engaging school experiences and experienced well-being. The investigation concerned seventh graders' sense of belonging in teacher-student and peerrelations as well as their school-related anxiety and cynicism. Interrelations between the profiles and gender, school achievement and student group (i.e., those in general education vs. those in special education) were also analysed. Accordingly, four complementary hypotheses were tested:

1. The components of emotional engagement, i.e., sense of belonging in teacherstudent and peer-group relations, correlate positively with each other (Pietarinen et al., 2014; Wang \& Holocombe, 2010) and, in turn, negatively with experienced anxiety and cynicism related to schoolwork (Pietarinen, Soini, \& Pyhältö, 2010; Pyhältö et al., 2010; Ryan \& Patrick, 2001; Tulis \& Fulmer, 2013; Wang \& Holocombe, 2010).

2. Students' experienced anxiety and cynicism, i.e., school- related well-being related to schoolwork correlate positively with each other (Pietarinen et a. 2014; Salmela-Aro et al., 2008); Salmela-Aro et al., 2009).

3. Various profiles of emotional engagement and school-related well-being can be identified (e.g., Korhonen, 2016; Lam et al., 2012; Lee, 2012; Lichtenfield et al., 2012; Oelsner et al., 2010; Salmela-Aro et al., 2008; Yuksel \& Geban, 2016) that are related to school achievement (Milsom \& Glanville, 2009; Salmela-Aro et al., 2009; Reschly \& Christenson, 2006; Tulis \& Fulmer, 2013; Wu et al., 2010) and gender (e.g., Korhonen, 2016; Lam et al., 2012; Lee, 2012; Lichtenfield et al., 2012; Oelsner et al., 2010; Salmela-Aro et al., 2008; Yuksel \& Geban, 2016).

4. Students in general education differ from those in special education in terms of both their sense of belonging in teacher-student and peer-group relations and experienced anxiety and cynicism related to schoolwork (e.g., Anderson et al., 2004; Finn \& Rock, 1997; Hughes; Im; \& Wehrly, 2014; Linnakylä \& Malinen, 2008; Lovitt et al., 1999; McGrath \& Bergen, 2015; Reschly \& Christensen, 2006).

\subsection{The research context: Finnish comprehensive school}

The school career of Finnish children typically starts with pre-primary school (which is compulsory) at the age of six. They continue with compulsory comprehensive education at the age of seven, which includes primary (grades 1-6) and secondary (grades 7-9) school. Schooling is publicly funded and includes the provision of free lunches and dental and health care. There is no private school system. Moreover, there are no ability- tracking or other structures assigning students at comprehensive school early on to either academic or vocational education (School Statistics, 
Official Statistics of Finland, 2012). The Finnish school system has flexible accountability structures that place a strong emphasis on allowing schools to regulate themselves (Aho, Pitkänen, \& Sahlberg, 2006). The main objective of the Finnish education policy is to offer all citizens an equal opportunity to receive an education, regardless of age, domicile, financial situation, gender or mother tongue. The right to free basic education is guaranteed for all students. Moreover, the new educational law emphasizes the principle of inclusion and aims at including students with special educational needs in mainstream instruction (Basic Education Act, 628/1998). Given that both Finnish and Swedish are official languages in Finland, basic education is provided in both languages. Each pupil has the right to receive remedial instruction and special-needs education when necessary. Hence, the Finnish comprehensive school offers a nine-year comprehensive curriculum for the whole age group (The Finnish National Board of Education, 2016).

\subsection{Participants and data collection}

The data were collected from one cohort comprising seventh graders attending all five Swedish-speaking secondary schools within the capital area of southern Finland representing the Swedish-speaking minority. The participants of this study were Swedish-speaking language minority general and special education students in Finland. The special education students in secondary schools are mostly mainstreamed in general education classes but receive additional support when needed. The case schools included variation in terms of size and were situated all around the Helsinki metropolitan area. Seventh graders were chosen as participants because they had just undergone the transition from primary to secondary school and therefore faced significant challenges and opportunities related to learning, well- being and social relations (Pietarinen et al., 2010; Pyhältö et al., 2010). A total of 119 students responded to the survey (94 in general education; 25 in special education). The students in general education comprised 55 per cent boys and 45 per cent girls, the respective proportions in special education being 71 and 29 per cent. The students were 12-14 years of age. The total response rate was 38 per cent. The data were collected with the ECW survey, i.e., Comprehensive students 'experienced emotional and cognitive engagement and school-related well-being (Pietarinen et al., 2014) in 2011-2012, at one time point from all schools as part of the researcher's fieldwork. Student contact information was received from the principal of each school. Parents were informed about the date of the survey and were asked for their consent for their children's participation, which was voluntary. Pupils were given verbal and written instructions for completing the survey, which took between 15 and $35 \mathrm{~min}$.

\subsection{The ECW survey}

The ECW survey (Pietarinen et al., 2014) includes scales measuring students' emotional engagement in teacher-student and peer relations, and school-related wellbeing in terms of anxiety and cynicism. Emotional engagement is measured on two complementary scales (Pietarinen et al., 2014) (1) teacher-student relations (8 
items, $\alpha=0.83$ ), and (2) peer-group relations ( 5 items, $\alpha=0.76$ ), and describes the students' sense of belonging in terms of the positive effects of social relations in the school context. The school-related anxiety (6 items, $\alpha=0.67)$ and cynicism (5 items, $\alpha=0.79$ ) scales (Pietarinen et al., 2014) indicate negative affects in schoolrelated well-being. All the scales have been validated in prior studies (Ulmanen et al., 2016). The students rated all items on a five-point Likert scale (1 strongly disagree; 5 strongly agree). The questionnaire items were translated from Finnish into Swedish, and the accuracy of the translation was verified by another researcher. Appendix 1 lists the scale items. Socio-demographic background information included the students' age and gender. Other relevant information concerned their grade point averages from the autumn term of 2011 and their grouping in terms of special and general education were collected from the principal and special teacher of each school.

\subsection{Data analysis}

The IBM SPSS Statistics 22 program was used for the analyses. Means, standard deviations and correlations between the scales were calculated to examine experienced emotional engagement and school-related well-being. Cluster analyses were conducted to further examine student profiles of emotional engagement and schoolrelated well-being based on individual response patterns. The mean scores for engagement in teacher-student and peer interaction, anxiety and cynicism were used as profile indicators. First, we conducted a hierarchical cluster analysis to determine the number of clusters, and this produced a four-cluster solution based on the agglomeration schedule. Having decided on the number, we carried out a K-means cluster analysis (Hair, Black, Babin, Anderson \& Tathan, 2016) to determine the final clusters. The relations of the profiles with gender and student group (special and general education) were examined by means of cross-tabulation. We conducted a Chi-square test to assess the association with gender, and a Fisher-Freeman-Halton exact test to determine the association with the student group given the small, expected counts. A one-way analysis of variance was used to examine whether the profiles differed in terms of the grade point average (GPA).

\section{Results}

\subsection{Levels of emotional engagement and school-related anxiety and cynicism}

Table 1 lists the correlations of the sub-scales, the means, standard deviations and ranges: all the bivariate correlations among the sub-scales were statistically significant and in the expected directions.

The results indicate that the students perceived a relatively high level of emotional engagement, in other words a sense of belonging, in teacher-student relationships $(M=3.5)$, but even higher levels of engagement in peer relations $(M=3.9)$. At the same time, they experienced low levels of study-related anxiety $(M=2.5)$ and cynicism 
Table 1 Descriptive statistics $(N=119)$

Correlations

$M$

$S D \quad$ Range

(1)

(2)

(3)

(4)

(1) Teacher-student

(2) Peer

(3) Anxiety

(4) Cynicism

5) GPA

$* p<0.05, * * p<0.01$

$(M=2.2)$. The correlations are consistent with hypotheses 1 and 2: emotional engagement in teacher-student and peer-group relations correlated positively with each other $(r=0.31)$. As expected, experienced school-related anxiety and cynicism correlated positively with each other $(r=0.47)$, and negatively with a sense of belonging in teacher-student and peer relations $\left[r^{(\min -\max )}=-0.19--0.50\right]$ : for example, the stronger the students' perceptions of not getting along with their teachers or peers, the more anxiety they experienced in terms of school issues in their free time. Moreover, higher levels of experienced cynicism and anxiety among the students related to more negative relationships with their teachers and peers. Being afraid of failing (anxiety-scale) was associated with perceptions of not receiving enough feedback from teachers, for example, and a lack of interest in going to school (cynicism-scale) related to negative peer relations. We examined individual variation in the student profiles more closely to shed further light on the intertwined nature of experienced emotional engagement (i.e., a sense of belonging constructed in teacher-student and peer relations) and perceived school-related anxiety and cynicism.

\subsection{Profiles of emotional engagement, school anxiety and cynicism}

Four profiles combining perceived emotional engagement in teacher-student and peer relations, and experiences of anxiety and cynicism were identified based on the cluster analysis. Table 2 presents the means and the standard deviations.

The profiles were: (1) moderately engaged in student-teacher interaction and emotionally highly engaged in peer interaction, combined with a low risk of anxiety and cynicism (i.e., moderate-high-low-low, $\mathrm{n}=50$ ); (2) emotionally disengaged in teacher-student interaction, and moderately engaged in peer interaction combined with a low risk of study-related anxiety and cynicism (i.e., low-moderate-low-low, $\mathrm{n}=14)$; ((3) moderately engaged in student-teacher interaction and emotionally disengaged in peer interaction, combined with a low risk of study-related cynicism and anxiety (i.e., moderate-low-low-low, $\mathrm{n}=15$ ); (4) emotionally highly engaged in both teacher-student and peer interaction combined with no significant risk of studyrelated anxiety or cynicism (i.e., high-high-low-low, $\mathrm{n}=40$ ).

The first group, i.e., moderate-high-low-low, represented the most dominant profile among the students. Its members characteristically showed a high sense of belonging in terms of peer relationships combined with a moderate sense in terms of teacher-student relations, while experiencing somewhat low levels of anxiety and 
Table 2 The profiles of emotional engagement and school anxiety and cynicism

\begin{tabular}{|c|c|c|c|c|c|c|c|c|c|}
\hline \multirow[t]{2}{*}{ Profiles } & \multicolumn{2}{|c|}{$1(n=50)$} & \multicolumn{2}{|c|}{$2(n=14)$} & \multicolumn{2}{|c|}{$3(n=15)$} & \multicolumn{2}{|c|}{$4(n=40)$} & \multirow[t]{2}{*}{119} \\
\hline & $\mathrm{M}$ & $\mathrm{SD}$ & $\mathrm{M}$ & SD & $\mathrm{M}$ & SD & $\mathrm{M}$ & $\mathrm{SD}$ & \\
\hline Teacher-student- relationship & $3.34^{\mathrm{a}}$ & 0.24 & 2.38 & 0.42 & $3.14^{\mathrm{a}}$ & 0.44 & 4.18 & 0.30 & \\
\hline Peer relationship & $4.14^{\mathrm{b}}$ & 0.40 & 3.64 & 0.48 & 2.58 & 0.67 & $4.13^{\mathrm{b}}$ & 0.48 & \\
\hline Anxiety & $2.61^{\mathrm{c}}$ & 0.65 & $2.83^{\mathrm{c}}$ & 0.69 & $2.88^{\mathrm{c}}$ & 0.76 & 2.21 & 0.73 & \\
\hline Cynicism & $2.47^{\mathrm{d}}$ & 0.80 & $2.89^{\mathrm{d}}$ & 1.02 & $2.44^{\mathrm{d}}$ & 0.66 & $1.62^{\mathrm{d}}$ & 0.63 & \\
\hline
\end{tabular}

Means with the same superscripts within a row are not significantly different at the $p<.05$ level

cynicism. The second profile, i.e., low-moderate-low-low, represents the smallest group. These students experienced a weaker sense of belonging in teacher-student relations, although they were still moderately engaged in peer relations. Moreover, their risk of experiencing study-related anxiety and cynicism was low, albeit higher than their sense of belonging in teacher-student relationships. The students comprising the third profile, i.e., moderate-low-low-low, experienced reduced levels of emotional engagement in peer relations, but still reported moderate levels of emotional engagement in teacher-student interaction. In other words, they were confident in their teachers - and they showed no risk of study-related anxiety or cynicism. The second most common profile was the fourth one, high-high-low-low. Students fitting this profile experienced a high sense of belonging in both teacher-student and peer relations, combined with the lowest levels of anxiety and cynicism of all the profiles. In general, these students emphasised teacher-student and peer interaction more than the others and showed low levels of school-related anxiety and cynicism. Hence, the results support hypothesis 3 in showing the existence of different emotional-engagement profiles reflecting a sense of belonging in teacher-student and peer interaction as well as school-related anxiety and cynicism.

\subsection{Interrelations between the profiles and gender, school achievement and student group}

No gendered differences in the emotional-engagement and well-being profiles were detected. Nor were there any statistically significant connections related to gender differences among the four profile groups $\left(x^{2}=1.72, d f=3, p=0.63\right)$. Accordingly, girls and boys were rather equally represented in all four groups. In other words, they had quite similar experiences of a sense of belonging in terms of teacher-student and peer relations as well as anxiety and cynicism, a result that does not support hypothesis 3 . This, in turn, could indicate that a sense of belonging combined with perceived school-related anxiety and cynicism vary similarly among girls and boys in everyday school life. More specifically, the individual risk factors seem to have a stronger impact on perceived emotional engagement, school anxiety and cynicism than gender. Further investigation showed that the four profile groups did not differ statistically significantly in terms of school achievement, i.e., grade point average $(p=0.07)$. 
Table 3 The profiles of emotional engagement and student groups

\begin{tabular}{|c|c|c|c|}
\hline & $\begin{array}{l}\text { Special education students } \\
(\mathrm{n}=25)\end{array}$ & $\begin{array}{l}\text { General education students } \\
(\mathrm{n}=94)\end{array}$ & Total \\
\hline \multicolumn{4}{|l|}{ Profile } \\
\hline 1 & $\mathrm{n}=8$ & $\mathrm{n}=42$ & 50 \\
\hline Within profile $(\%)$ & 16.0 & 84.0 & \\
\hline Within student group (\%) & 32.0 & 44.7 & \\
\hline Total (\%) & 6.7 & 35.3 & \\
\hline Std. Residual & -.8 & .4 & \\
\hline 2 & $\mathrm{n}=2$ & $\mathrm{n}=12$ & 14 \\
\hline Within profile $(\%)$ & 14.3 & 85.7 & \\
\hline Within student group (\%) & 8.0 & 12.8 & \\
\hline Total (\%) & 1.7 & 10.1 & \\
\hline Std. Residual & -.5 & .3 & \\
\hline 3 & $\mathrm{n}=8$ & $\mathrm{n}=7$ & 15 \\
\hline Within profile $(\%)$ & 53.3 & 46.7 & \\
\hline Within student group (\%) & 32.0 & 7.4 & \\
\hline Total $(\%)$ & 6.7 & 5.9 & \\
\hline Std. Residual & 2.7 & -1.4 & \\
\hline 4 & $\mathrm{n}=7$ & $\mathrm{n}=33$ & 40 \\
\hline Within profile $(\%)$ & 17.5 & 82.5 & \\
\hline Within student group (\%) & 28.0 & 35.1 & \\
\hline Total $(\%)$ & 5.9 & & 27.7 \\
\hline Std. Residual & -.5 & .2 & \\
\hline
\end{tabular}

Fisher's exact test $=8.98 ; p=.023$

However, there were statistically significant differences among the profile groups, in terms of teacher-student and peer relations and school-related anxiety and cynicism, between students in general education and those in special education $(p=0.02)$.

As Table 3 shows, there was an interrelationship between the profiles and the student groups. Profile group 3 was overrepresented by students in special education (32\%) in comparison with those in general education (7.4\%). The students in this group were moderately emotionally engaged in their teacher-student relationships although experiencing low levels of emotional engagement in peer-group relations combined with low levels of experienced anxiety and cynicism. For example, students in special education reported not being popular among their schoolmates, implying a low sense of belonging among their peers, while experiencing moderate levels of support from their teachers. On the other hand, profile group 1 had the highest proportion of students in general education (44.7\%). This group comprised students who were emotionally engaged in terms of peer relationships, but moderately engaged in teacher-student relations, with low levels of experienced anxiety and cynicism. However, peer relations were perceived as the most emotionally engaging indicator. For example, students rated their significance in terms of being popular among their school mates, and 
their moderate sense of belonging in terms of feeling that their teachers cared for them was related to low-level experiences of anxiety and cynicism, meaning that school was a place in which they felt comfortable and valued. These findings are supportive of hypothesis 4: students in general education on the one hand, and in special education on the other, may perceive a sense of belonging in terms of both teacher-student and peer-group relations and experienced schoolworkrelated anxiety and cynicism somewhat differently.

\section{Discussion}

\subsection{The results in the light of previous research}

We adopted a socio-contextual, person-centred approach to explore individual variation among students in emotionally engaging school experiences and perceived school-related anxiety and cynicism among the Swedish- speaking language minority group students in Finland. We also explored the interrelations between the profiles employed by these students and gender, school achievement and student groups. The findings indicate that the extent to which a student feels supported by teachers and personally accepted by peers, and experiences low levels of anxiety and cynicism, is a major determinant of emotionally engaging school experiences. In addition, peer acceptance and experiences of fair treatment by and emotional support from teachers contribute to reducing the risk experiencing school-related anxiety and cynicism (Pietarinen et al., 2010; Pyhältö et al., 2010; Ryan \& Patrick, 2001; Tulis \& Fulmer, 2013; Wang \& Holocombe, 2010). Our results are consistent with the findings of previous studies (e.g. Pietarinen et al., 2010; Pyhältö et al., 2010; Wu et al., 2010) showing that a sense of belonging and good relations with teachers and peers constitute the core of emotionally engaging experiences contributing to student well-being. Moreover, the findings complement previous research in indicating that experiencing emotional support from teachers also has a positive effect on peer relations (Palmgren et al., 2017; Pietarinen et al., 2014; Pyhältö et al., 2010; Wang \& Holocombe, 2010). It seems thar emotional engagement in teacher-student and peer group relations were higher among the Swedish-speaking students in the present study, compared to an another study concerning Finnish-speaking students (Pietarinen et al., 2014). The implication is that students' emotional engagement is highly socially embedded in interactions with peers and teachers.

In prior studies a positive relationship between emotional engagement and school achievement have been detected (e.g., Milsom \& Glanville, 2009; Salmela-Aro et al., 2009; Reschly \& Christenson, 2006; Wu et al., 2010). This includes an earlier study conducted with Finnish-speaking students (Pietarinen et al., 2014). Yet, we did not detect an association between the emotional-engagement, school-anxiety and cynicism- profiles and school achievement among the students presenting the Swedish -speaking Finnish language minority group. Neither were gendered differences in profiles employed by girls and boys identified. This is contradictory to findings from some earlier studies suggesting the presence of gendered differences, to the advantage of girls, in experienced emotional engagement in school activities (e.g., Korhonen, 2016; Oelsner et al., 2010; Salmela-Aro et al., 2008). A possible reason for this, as suggested in prior studies, is 
that emotional engagement in peer relationships does not always enhance academic performance among students (e.g., Chen et al., 2010; You, 2011), and those students may engage in school for different reasons (e.g., Lawson \& Masyn, 2015; Linnakylä \& Malin, 2008). This does not however explain why the quality of the teacher-student relationship did not have strong association with students' school achievement as suggested by prior studies (e.g., Upadyaya \& Salmela-Aro, 2011; Virtanen et al., 2014).

Finally, our analysis identified individual variations in experiences of emotional engagement and differences between the four student-profile groups among students in both general and special education. These findings are in line with those reported in earlier studies indicating that students in special education do not always feel that they are sufficiently supported or fairly treated by their teachers (e.g., Linnakylä \& Malinen, 2008). They may also feel that they need more teacher support in developing their social skills and peer relations (e.g., Anderson et al., 2004). Thus, it seems that students in special education have different experiences of emotional engagement than their age-matched peers. Overall, the findings reflect the need to construct functional student-teacher and peer relations to ensure an emotionally engaging school experience for students, especially those in special education.

\subsection{Methodological limitations}

A self-report survey combined with grade point averages were used to capture experienced emotional engagement and school-related well-being among seventh graders at Finland-Swedish middle schools in Helsinki. The survey and the grade point average enabled us to explore school experiences retrospectively among these students in both general and special education. The core limitations of the study relate to the cross-sectional design and the small sample size. The cross-sectional nature of the data may give rise to causal interpretations about the interrelations between the variables. Moreover, given the low response rate (attributable primarily to the practical difficulties of contacting parents by letter or e-mail) and the small number of participants in both groups (students in both general and special education), the results cannot be generalized to the Finland-Swedish population. However, the representativeness of the sample could be considered sufficient among both student groups, especially given that all the relevant middle schools participated in the study. Hence, these findings complement those from earlier studies on emotional engagement and its association with school-related anxiety and cynicism, especially among the students within the middle schools in question.

Nevertheless, further research is needed to explore individual variation in emotional engagement and school-related well-being among larger samples and in other contexts, and to generate a deeper understanding of students' emotional engagement in inclusive school settings. One could focus, for instance, on the tensions within the profile groups of emotional engagement and the differences in responses between students in general as opposed to special education. It would also be useful to gain further insights into the development of different student profiles. 


\section{Conclusion}

This study highlights the complexity of emotional engagement among students in terms of a sense of belonging in teacher-student and peer relations and experienced school-related anxiety and cynicism. The identification of student profiles that differ in terms of emotional engagement in school and experienced anxiety and cynicism related to gender, school achievement and student group (general vs. special education) could enhance understanding about the complexity of emotional engagement and facilitate the development of tools to improve school practice. Our results imply that students' emotional engagement is socially embedded. Thus, it is not an individual attribute but is constructed in interaction among teachers and peers. There was individual variation among the students in terms of experienced emotional engagement, as well as differences between the students in general and special education. We therefore suggest that different measures need to be taken to enhance emotional engagement among students depending on their engagement profile. This calls for the development of school practices that provide different types of social support to fit the varying needs of students, offer enough opportunities for participation (Pietarinen et al., 2010) and include training in social skills (Milsom \& Glanville, 2010).

Moreover, school-related anxiety and cynicism could be understood as co-varying determinants of emotional engagement in terms of teacher-student and peer relations: high levels of a sense of belonging in student- teacher and peer relationships were combined with the lowest risk of experiencing school-related anxiety and cynicism. This result could be considered encouraging, implying that the school environment, at its best, could enhance both emotional engagement and well-being among students. If they are to fulfil this potential, however, they need to acquire functional social strategies that enable them to connect with their significant others at school. The gains of such investment are likely to be significant, including enhancing both the joy of learning (e.g., Korhonen, 2016; Ulmanen et al., 2016) and reducing the amount of loneliness and drop-out from school (e.g., Salvatore et al.). The learning of such skills would be beneficial to all students, but particularly to those in special education, who run a greater risk of peer exclusion. The present study makes a dual contribution to the body of knowledge on student emotional engagement and school related anxiety and cynicism. Firstly, it shed light on the complex interrelation between the student's emotional engagement in teacher-student and peer relations and experienced anxiety and cynicism by identifying four distinct emotional engagement-study well-being profiles. Secondly, it detected differences in profiles employed by the general and special education students presenting Swedish-speaking language minority group in Finland, which according to our knowledge has not been previously studied.

\section{Appendix 1}

See Table 4. 
Table 4 The scales and the items

\begin{tabular}{ll}
\hline Scale & Items \\
\hline $\begin{array}{l}\text { Emotional engagement } \\
\text { Teacher-student }\end{array}$ & $\begin{array}{r}\text { The teacher often gives me encouraging feedback. In our school the teachers } \\
\text { listen to the students. Most teachers know how to teach. I can be myself at } \\
\text { school. Most teachers are enthusiastic about their work. I feel the teachers } \\
\text { care about me. I get along well with my teachers. The teachers treat me fairly } \\
\text { I have a lot of mates in school. I'm popular among my mates. I feel the other } \\
\text { students like me. We have a nice class spirit in our class. I believe my circle } \\
\text { of mates will stay together in the future as well } \\
\text { Peer } \\
\text { I am often quite exhausted after the school day is over. In school I often worry } \\
\text { about unpleasant things at home. I often must study too hard in school. } \\
\text { School worries occupy my thoughts during my free time. I am afraid of fail- } \\
\text { ing at something in school. School makes me feel uncomfortable } \\
\text { Going to school doesn't interest me at all. I often feel like playing hook from } \\
\text { school. Going to school feels unnecessary. Often, I feel I really don't want to } \\
\text { come to school. We must study some quite useless stuff }\end{array}$ \\
Cynicism &
\end{tabular}

Funding Open access funding provided by University of Helsinki including Helsinki University Central Hospital. This study was supported by the Otto A. Malm fund and The Swedish Cultural Foundation in Finland (Grant No. 8000euro). The funf was provided by Oskar Öflunds Fund (FI) (Grant No. 3000euro).

Data availability No data are available because of the anonymity of the participants.

Code availability All data and material as well as software applications support our published claims.

\section{Declarations}

Conflict of interest The authors declare no potential conflict of interest.

Ethical approval This research follows the ethical standards of the Finnish National Board on Research Integrity (TENK).

Consent to participate We give our consent to participate.

Consent for publication We give our concent for publication.

Open Access This article is licensed under a Creative Commons Attribution 4.0 International License, which permits use, sharing, adaptation, distribution and reproduction in any medium or format, as long as you give appropriate credit to the original author(s) and the source, provide a link to the Creative Commons licence, and indicate if changes were made. The images or other third party material in this article are included in the article's Creative Commons licence, unless indicated otherwise in a credit line to the material. If material is not included in the article's Creative Commons licence and your intended use is not permitted by statutory regulation or exceeds the permitted use, you will need to obtain permission directly from the copyright holder. To view a copy of this licence, visit http://creativecommons.org/licen ses/by/4.0/.

\section{References}

Adhiambo, W. M., Odwar, A. J., \& Mildred, A. A. (2016). The relationship between school burnout gender and academic achievement amongst secondary school students in Kisumu East 
Subcounty Kenya. Journal of Emerging Trends in Educational Research and Policy Studies (JETERAPS), 7(5), 326-331. https://doi.org/10.19044/esj.2017.v13n1p247

Aho, E., Pitkänen, K., \& Sahlberg, P. (2006). Policy development and reform principles of basic and secondary education in Finland since 1968. Finland: World Bank.

Akiva, T., Cortina, K. S., Eccles, J. S., \& Smith, C. (2013). Youth belonging and cognitive engagement in organized activities: A large-scale field study. Journal of Applied Developmental Psychology, 34, 208-218. https://doi.org/10.1016/j.appdev.2013.05.001

Anderson, A. R., Christenson, S. L., Sinclair, M. F., \& Lehr, C. A. (2004). Check \& connect: The importance of relationships for promoting engagement with school. Journal of School Psychology, 42, 95-113. https://doi.org/10.1016/j.jsp.2004.01.002

Appleton, J. J., Christenson, S. L., Kim, D., \& Reschly, A. (2006). Measuring cognitive and psychological engagement: Validation of the student engagement instrument. Journal of School Psychology, 44, 427-445. https://doi.org/10.1016/j.jsp.2006.04.002

Audas, R., \& Willms, J. D. (2001). Engagement and dropping out of school: A life-course perspective (W-01-1-10-E). Human Resources Development Canada: Applied Research Branch Strategic Policy.

Baker, J. A., Clark, T. P., Maier, K. S., \& Viger, S. (2008). The differential influence of instructional context on the academic engagement of students with behaviour problems. Teaching and Teacher Education, 24, 1876-41883. https://doi.org/10.1016/j.tate.2008.02.019

Battistich, V., \& Hom, A. (1997). The relationship between students 'sense of their school as a community and their involvement in problem behaviours. American Journal of Public Health, 87, 1997-2001. https://doi.org/10.2105/AJPH.87.12.1997

Belfi, B., Goos, M., De Fraine, B., \& Van Damme, J. (2012). The effect of class composition by gender and ability on secondary school students 'school well-being and academic self-concept: A literature review. Educational Research Review, 7, 62-74. https://doi.org/10.1016/j.edurev. 2011.09.002

Bendelow, G., \& Mayall, B. (2002). Children's emotional learning in primary schools. European Journal of Psychotherapy, Counselling \& Health, 5(3), 291-304. https://doi.org/10.1080/13642 53031000091390

Bossaert, G., Colpin, H., Pijl, J. S., \& Petry, K. (2012). Loneliness among students with special educational needs in mainstream seventh grade. Research in Developmental Disabilities, 32, 18881897. https://doi.org/10.1016/j.ridd.2012.05.010

Cappellla, E., Kim, H. Y., Neal, J. W., \& Jackson, D. R. (2013). Classroom peer relationships and behavioural engagement in elementary school: The role of social network equity. American Journal Community Psychology, 52, 367-4379. https://doi.org/10.1007/s10464-013-9603-5

Caraway, K., Tucker, C. M., Reinke, W. M., \& Hall, C. (2003). Self-efficacy, goal orientation, and fear of failure as predictors of school engagement in high school students. Psychology in the School, 40(4), 417-427. https://doi.org/10.1002/pits.10092

Carbonaro, W. (2013). Dropping out of high school: Effects of close and distant friendships. Social Science Research, 42, 1254-1268. https://doi.org/10.1016/j.ssresearch.2013.05.003

Chen, Q., Hughes, J. N., \& Kwok, Q.-M. (2010). Joint contributions of peer acceptance and peer academic reputation to achievement in academically at-risk children: Mediating processes. Journal of Applied Developmental Psychology, 31(6), 448-459. https://doi.org/10.1016/j.appdev.2010. 09.001

Cummins, J., \& Swain, M. (Eds.). (2014). Bilingualism in education. Aspects of theory, research and practice. Routledge.

Denham, S. A., Bassett, H., Minic, M., Kalb, S., Way, E., Wyatt, T., \& Segal, Y. (2012). Social-emotional learning profiles of pre-schoolers' early school success: A person-cantered approach. Learning and Individual Differences, 22(2), 178-189. https://doi.org/10.1016/j.lindif.2011.05.001

Elffers, L., Oort, F. J., \& Karsten, S. (2012). Making the connection: The role of social and academic school experiences in students' emotional engagement with school in post -secondary vocational education. Learning and Individual Differences, 22, 242-250. https://doi.org/10.1016/j.lindif.2011. 08.005

Fall, A.-M., \& Roberts, C. (2012). High school dropouts: Interactions between social context, selfperceptions, school-engagement, and student dropout. Journal of Adolescence, 35(4), 787-798. https://doi.org/10.1016/j.adolescence.2011.11.004 
Filippello, P., Marino, F., Spadaro, L., \& Sorrenti, L. (2013). Learning disabilities and social problemsolving skills. Mediterranean Journal of Clinical Psychology MJCP., 1(2), 2-23. https://doi.org/ 10.6092/2282-1619/2013.2.911

Finn, J. D. (1993). School engagement and students at risk. National Centre for Education Statistics.

Finn, J. D. F., \& Voelkl, K. E. (1993). School characteristics related to student engagement. The Journal of Negro Education, 62(3), 249-268. https://doi.org/10.2307/2295464

Finn, J. D., \& Rock, D. A. (1997). Academic success among students at risk for school failure. Journal of Applied Psychology, 82(2), 221-234. https://doi.org/10.1016/j.jadohealth.2012.06.019

Fredricks, J. A., Blumenfield, P. C., \& Paris, A. H. (2004). School engagement: Potential of the concept, state of the evidence. Review of Educational Research, 74(1), 59-109. https://doi.org/10.3102/ 00346543074001059

Furlong, M. J., \& Christenson, S. L. (2008). Engaging students at school and with learning: A relevant construct for all students. Psychology in the Schools, 45(5), 365-368. https://doi.org/10.1002/pits. 20302

Furrer, C. J. (2010). Capturing the friendship context with a collective property: Friendship group engagement vs. disaffection. Journal of Adolescence, 33, 853-867. https://doi.org/10.1016/j.adole scence. 2010.07 .003

Furrer, C., \& Skinner, E. (2003). Sense of relatedness as a factor in children's academic engagement and performance. Journal of Educational Psychology, 95(1), 148-162. https://doi.org/10.1037/00220663.95.1.148

Hair, J. F., Black, W. C., Babin, B. J., Anderson, R. E., \& Tatham, R. L. (Eds.), Multivariate data analysis. Upper Saddle River: Prentice Hall cop. 2016. 6th edition.

Han, W. J. (2010). Bilingualism and socioemotional well-being. Children and Youth Services Review, 32, 720-731. https://doi.org/10.1016/j.childyouth.2010.01.009

Harel-Fisch, Y., Fogel-Grinvald, S. D., Pickett, H., Molcho, W., Due, M., de Matos, G. P., \& Craig, W. (2011). Negative school perceptions and involvement in school bullying: A universal relationship across 40 countries. Journal of Adolescence, 34(4), 639-652. https://doi.org/10.1016/j.adole scence. 2010.09 .00

Hargreaves, A. (2000). Mixed emotions: Teachers' perceptions of their interactions with students. Teacher and Teacher Education, 16(8), 811-826. https://doi.org/10.1016/s0742-051x(00)00028-7

Hart, S. N. (2014). Children's rights and school psychology: Historical perspective and implications for the profession. School Psychology International, 35(1), 6-28. https://doi.org/10.1177/0143034313 508875

Hughes, J. N., Im, M. H., \& Wehrly, S. E. (2014). Effect of peer nominations of teacher-student support at individual and classroom levels on social and academic outcomes. Journal of School Psychology, 52(3), 309-322. https://doi.org/10.1016/j.jsp.2013.12.004

Janosz, M., Le Blanc, M., Boulerice, B., \& Tremblay, R. E. (2000). Predicting different types of school dropouts: A typological approach with two longitudinal samples. Journal of Educational Psychology, 92(1), 171-190. https://doi.org/10.1037/0022-0663.92.1.171

Jindal-Snape, D., \& Miller, D. J. (2008). A challenge of living? Understanding the psycho-social processes of the child during primary-secondary transition through resilience and self-esteem theories. Educational Psychological Reviev, 20, 217-236.

King, R. B. (2015). Sense of relatedness boosts engagement, achievement, and well-being: A latent growth model study. Contemporary Educational Psychology, 42, 26-38. https://doi.org/10.1016/j. cedpsych.2015.04.002

Korhonen, J. (2016). Learning difficulties, academic well-being and educational pathways among adolescent students (Doctoral thesis, Special Education, Faculty of Education and Welfare Studies, Åbo Academy University, Vasa, Finland).

Lam, S., Jimerson, S., Kikas, E., Cefai, C., Veiga, F., Nelson, B., \& Zolleritsch, J. (2012). Do girls and boys perceive themselves as equally engaged in school? The results of an international study from 12 countries. Journal of School Psychology, 50, 77-94. https://doi.org/10.1016/j.jsp.2011.07.004

Langher, V., Ricci, M. E., Reversi, S., \& Citarelli, G. (2010). Disabled students and the quality of relationships within the class. Procedia Social and Behavioural Sciences, 5, 2295-2299. https://doi. org/10.1016/j.sbspro.2010.07.452

Lappalainen, K., Savolainen, H., Kuorelahti, M., \& Epstein, M. H. (2009). An international assessment of the emotional and behavioural strengths of youth. Journal of Child and Family Studies, 18(6), 746-753. https://doi.org/10.1007/s10826-009-9287-5 
Lawson, M. A., \& Mason, K. E. (2015). Analysing profiles, predictors, and consequences of student engagement dispositions. Journal of School Psychology, 53, 63-86. https://doi.org/10.1016/j.jsp. 2014.11.004

Lee, J.-S. (2012). The effects of the teacher-student relationship and academic press on student engagement and academic performance. International Journal of Educational Research, 53, 330-340. https://doi.org/10.1016/j.ijer.2012.04.006

Lichtenfield, S., Pekrun, R., Stupnisky, R. H., Reiss, K., \& Murayama, K. (2012). Measuring students "emotions in the early years: The achievement emotions questionnaire - elementary school (AEQES). Learning and Individual Differences, 22, 190-201. https://doi.org/10.1016/j.lindif.2011.04. 009

Linnakylä, P., \& Malin, A. (2008). Finnish students 'school engagement profiles in the light of PISA 2003. Scandinavian Journal of Educational Research, 52(6), 583-602. https://doi.org/10.1080/ 00313830802497174

Loingsigh, D. N., \& Mozzon-McPherson, M. (2020). Advising in language learning in a new speaker context: Facilitating linguistic shifts. System, 95, 102-363. https://doi.org/10.1016/j.system.2020. 102363

Lovitt, T., Plavins, M., \& Cushing, S. (1999). What do pupils with disabilities have to say about their experience in high school? Remedial and Special Education, 20(2), 67-83. https://doi.org/10.1177/ 074193259902000202

Maag, J. W., \& Reid, R. (2006). Depression among students with learning disabilities: Assessing the risk. Journal of Learning Disabilities, 39(1), 3-10. https://doi.org/10.1177/00222194060390010201

Mady, C., \& Muhling, S. (2017). Instructional supports for students with special education needs in French as a second language education: A review of Canadian empirical literature. Journal of Education and Learning, 6(3), 14-22. https://doi.org/10.5539/jel.v6n3p14

Magelinskaite, S., Kepalaite, A., \& Legkauskas, V. (2014). Relationship between social competence, learning motivation, and school anxiety in primary school. Procedia-Social and Behavioral Sciences, 116, 2936-2940. https://doi.org/10.1016/j.sbspro.2014.01.683

Maslac, C., \& Jackson, S. E. (1981). The measurement of experienced burnout. Journal of Occupational Behaviours, 2, 99-113. https://doi.org/10.1002/job.4030020205

Matzen, K., Ryndak, D., \& Nakao, T. (2010). Middle school teams increasing access to general education for students with significant disabilities: Issues encountered, and activities observed across contexts. Remedial and Special Education, 31(4), 287-304. https://doi.org/10.1177/0741932508 327457

McGrath, K. F., \& Van Bergen, P. (2015). Who, when why and to what end? Students at risk of negative student-teacher relationships and their outcomes. Educational Research Review, 14, 1-17. https:// doi.org/10.1016/j.edurev.2014.12.001

Midgley, C., \& Edelin, K. C. (1998). Middle school reform and early adolescent well-being: The good news and the bad. Educational Psychologist, 33, 195-206. https://doi.org/10.1207/s15326985e p3304_4

Milsom, A., \& Glanville, J. L. (2010). Factors mediating the relationship between social skills and academic grades in a sample of students diagnosed with learning disabilities or emotional disturbance. Remedial and Special Education, 31(4), 241-251. https://doi.org/10.1177/0741932508327460

Nurmi, J.-E. (2012). Students' characteristics and teacher-child relationships in instruction: A meta-analysis. Educational Research Review, 7, 177-197. https://doi.org/10.1016/j.edurev.2012.03.001

Nyqvist, F., Finnäs, F., Jakobsson, G., \& Koskinen, S. (2008). The effect of social capital on health: The case of two language groups in Finland. Health \& Place, 14(2), 347-360.

Oberle, E. (2013). Relations among peer acceptance, inhibitory control, and match achievement in early adolescence. Journal of Applied Developmental Psychology, 34(1), 45-51. https://doi.org/10. 1016/j.appdev.2012.09.003

Oelsner, J., Lippold, M. A., \& Greenberg, M. T. (2010). Factors influencing the development of school bonding among middle school students. The Journal of Early Adolescence, 31(3), 463-487. https:// doi.org/10.1177/0272431610366244

Osterman, K. F. (2000). Students' need for belonging in the school community. Review of educational research, 70,323-368. Children and Youth Service Review, 33, 829-839. https://doi.org/10.2307/ 1170786

Palmgren, M., Pyhältö, K., Pietarinen, J. \& Soini, T. (2017). Students’ engaging school experiences - a precondition for functional inclusive practice. International Journal of Whole Schooling, Special Issue. 26-49. 
Pedersen, S., Vitaro, F., Barker, E. D., \& Borge, A. I. H. (2007). The timing of middle-childhood peer rejection and rriendship: Linking early behaviour to early-adolescent adjustment. Child Development, 78(4), 1037-1051. https://doi.org/10.1111/j.1467-8624.2007.01051.x

Pietarinen, J., Soini, T., \& Pyhältö, K. (2010). Learning and well-being in transitions-How to promote pupil's active learning agency. In J. Snape (Ed.), Educational transitions Moving stories from around the world (pp. 143-158). Routledge.

Pietarinen, J., Soini, T., \& Pyhältö, K. (2014). Students' emotional and cognitive engagement as the determinants of well-being and achievement in school. International Journal of Educational Research, 67, 40-51. https://doi.org/10.1016/j.ijer.2014.05.001

Pijl, S. J., Skaalvik, E. M., \& Skaalvik, S. (2010). Students with special needs and the composition of their peer group. Irish Educational Studies, 29(1), 57-70. https://doi.org/10.1080/0332331090 3522693

PISA, Program for International Student Assessment. (2009). Results-OECD. Retrieved from http:// www.oecd.org/pisa/keyfindings/pisa-2009-results-overview.pdf

PISA, Program for International Student Assessment. (2012). Results-OECD. Retrieved from http:// www.oecd.org/pisa/keyfindings/pisa-2012-results-overview.pdf

PISA, Program for International Student Assessment. (2015). PISA 2015 Results in Focus. Retrieved from https://www.oecd.org/pisa/pisa-2015-results-in-focus.pdf

PISA, Program for International Student Assessment. (2018). PISA 2018 Results in Focus. Retrieved from https://www.oecd.org/pisa/publications/PISA2018_CN_FIN.pdf

Pitt, V., \& Curtin, V. (2004). Integration versus segregation: The experiences of a group of disabled students moving from mainstream school into special needs further education. Disability of Society, 19(4), 387-399. https://doi.org/10.1080/09687590410001689485

Pyhältö, K., Soini, T., \& Pietarinen, J. (2010). Pupil's pedagogical well-being in comprehensive schoolsignificant positive and negative school experiences of Finnish ninth graders. European Journal of Psychology of Education, 25(2), 207-221. https://doi.org/10.1007/s10212-010-0013-X

Reschly, A. M., \& Christenson, S. L. (2006). Prediction of dropout among students with mild disabilities: A case for the inclusion of student engagement variables. Remedial and Special Education, 27(5), 276-281. https://doi.org/10.1177/07419325060270050301

Roseth, C. J., Johnson, D. W., \& Johnson, R. T. (2008). Promoting early adolescents achievement and peer relationships: The effects of cooperative competitive and individualistic goal structures. Psychological Bulletin Copyright 2008 by the American Psychological Association, 134(2), 223-246. https://doi.org/10.1037/0033-2909.134.2.223

Rudolph, K. D., Agoston, A. M., Sugimura, N., Dodge, K. A., Lansford, J. E., Schwartz, D., \& Pettit, G. S. (2014). Peer victimization and social alienation: Predicting deviant peer affiliation in middle school. Child Development, 85(1), 124-139. https://doi.org/10.1111/cdev.12112

Ryan, A. M., \& Patrick, H. (2001). The classroom social environment and changes in adolescents' motivation and engagement during middle school. American Educational Research Journal, 38(2), 437-460. https://doi.org/10.3102/00028312038002437

Salmela-Aro, K., Kiuru, N., Pietikäinen, M., \& Jokela, J. (2008). Does school matter? The role of school context in adolescent's school-related burnout. European Psychologist, 13(1), 12-23. https://doi. org/10.1027/1016-9040.13.1.12

Salmela-Aro, K., Kiuru, N., Leskinen, E., \& Nurmi, J. (2009). School burnout inventory (SBI): Reliability and validity. European Journal of Psychological Assessment, 25, 48-57. https://doi.org/10. 1027/1015-5759.25.1.48

Salmela-Aro, K., Tolvanen, A., \& Nurmi, J.-E. (2011). Social strategies during university studies predict early career work burnout and engagement: 18-year longitudinal study. Journal of Vocational Behaviour, 79, 145-157. https://doi.org/10.1016/j.jvb.2011.01.002

Samdal, O., Wold, B., \& Bronis, M. (1999). Relationship between students 'perceptions of school environment, their satisfaction with school and perceived academic achievement: An international study. School Effectiveness and School Improvement: An International Journal of Research, Policy and Practice, 10(3), 296-320. https://doi.org/10.1076/sesi.10.3.296.3502

Sattoe, N. T., Hilberink, S. R., \& van Staa, B. R. (2014). Lagging or not? Four distinctive social participation patterns among young adults with chronic conditions. Journal of Adolescent Health, 54(4), 397-403. https://doi.org/10.1016/j.jadohealth.2013.09.017

School Statistics (2012). Official Statistics of Finland, (OSF): Entrance to education, Helsinki: Statistics Finland (e-publication: http://www.stat.fi/til/khak/2012/khak_2012_2014-01-23_tau_001_ en.html) (referred 19.3.18) 
Seligman, M. E. P., \& Csikszentmihalyi, M. (2000). Positive psychology. American Psychologist, 55(1), 5-14. https://doi.org/10.1037//0003-066x.55.1.5

Skinner, E. A., \& Belmont, M. J. (1993). Motivation in the classroom: Reciprocal effects of teacher behaviour and student engagement across the school year. Journal of Educational Psychology, 85, 571-581. https://doi.org/10.1037//0022-0663.85.4.571

Skinner, E. A., Kindermann, T., \& Furrer, C. (2009). A motivational perspective on engagement and disaffection: Conceptualization and assessment of children's behavioural and emotional participation in academic activities in the classroom. Educational and Psychological Measurement, 69, 493-524. https://doi.org/10.1177/0013164408323233

Sorrenti, L., Filippello, P., Orecchio, S., \& Buzzai, C. (2016). Learned helplessness and learning goals: role played in school refusal. A study on Italian students. Mediterranean Journal of Clinical Psychology MJCP. 10. 6092(2282.1619/2016.4.1235

Steinberg, L., \& Morris, A. S. (2001). Adolescent development. Annual Review of Psychology, 52, 83-110. https://doi.org/10.1146/annurev.psych.52.1.83

Stiglbauer, B., Gnambs, T., Gamsjäger, M., \& Batinic, B. (2013). The upward spiral of adolescents' positive school experiences and happiness: Investigating reciprocal effects over time. Journal of School Psychology, 51, 231-242. https://doi.org/10.1016/j.jsp.2012.12.002

Sulkowski, M. L., Demaray, M. K., \& Lazarus, P. J. (2012). Connecting students to schools to support their emotional well-being and academic success NASP National association of school psychologists Communique. Research-based practice, 40(7), 1-11.

The Finnish National Board of Education. (2016). Finnish education in a nutshell. Retrieved from http://www.oph.fi/download/146428_Finnish_Education_in_a_Nutshell.pdf.

Thijs, J., Westhof, S., \& Koomen, H. (2012). Ethnic incongruence and the student-teacher relationship: The perspective of ethnic majority teachers. Journal of School Psychology, 50, 257-273. https://doi.org/10.1016/j.jsp.2011.09.004

Tulis, M., \& Fulmer, S. M. (2013). Student's 'motivational and emotional experiences and their relationship to persistence during academic challenge in mathematics and reading. Learning and Individual Differences, 27, 35-46. https://doi.org/10.1016/j.lindif.2013.06.003

Ulmanen, S., Soini, T., Pietarinen, J., \& Pyhältö, K. (2016). The anatomy of adolescent's 'emotional engagement in schoolwork. Social Psychology of Education: An International Journal. https:// doi.org/10.1007/s11218-016-9343-0

Upadyaya, K., \& Salmela-Aro, K. (2011). School engagement: A multidimensional concept in context. Pathfinder the Pathways to Adulthood Newsletter, 3, 2-4.

Uusitalo-Malmivaara, L., Kankaanpää, P., Makinen, T., Raeluoto, R., Rauttu, K., Tarhala, V., \& Lehto, J. E. (2012). Are special education students happy? Scandinavian Journal of Educational Research, 56(4), 419-437. https://doi.org/10.1080/00313831.2011.599421

Uusitalo-Malmivaara, L. (2014). Happiness Decreases during early adolescence-a study on 12- and 15-Year-old. Finnish Students Psychology., 5, 541-555. https://doi.org/10.4236/psych.2014. 56064

Vincze, L., \& Harwood, J. (2015). Language competence as a moderator of ethno linguistic identity gratifications among three language minorities in Europe. Studies in Communication Sciences, $15,151-157$.

Virtanen, T. E., Lerkkanen, M. K., Poikkeus, A. M., \& Kuorelahti, M. (2014). Student behavioural engagement as a mediator between teacher, family, and peer support and school truancy. Learning and Individual Differences, 36, 201-206. https://doi.org/10.1016/j.lindif.2014.09

Wang, M.-T., Chow, A., Hofkens, T., \& Salmela-Aro, K. (2015). The trajectories of student emotional engagement and school burnout with academic and psychological development: Findings from Finnish adolescents. Learning and Instruction, 36, 57-65. https://doi.org/10.1016/j.learninstr uc. 2014.11.004

Wang, M.-T., Eccles, J., Willett, J., \& Peck, S. (2011). School engagement: A multi-dimensional and developmental concept in context. Pathfinder the Pathways to Adulthood Newsletter, 3, 2-4.

Wang, M.-T., \& Eccles, J. S. (2013). School context, achievement motivation, and academic engagement: A longitudinal study of school engagement using a multidimensional perspective. Learning and Instruction, 28, 12-23. https://doi.org/10.1016/j.learninstruc.2013.04.002

Wang, M.-T., \& Holocombe, R. (2010). Adolescent's perceptions of school environment, engagement and academic achievement in middle school. American Educational Research Journal, 47, 633-662. https://doi.org/10.3102/0002831209361209 
Wang, M. T., \& Peck, S. C. (2013). Adolescent educational success and mental health vary across school engagement profiles. Developmental Psychology, 49(7), 1266-1276.

Wang, M.-T., Willett, J. B., \& Eccles, J. (2011). The assessment of school engagement: Examining dimensionality and measurement invariance by gender and race/ethnicity. Journal of School Psychology, 49, 465-480. https://doi.org/10.1016/j.jsp.2011.04.001

Willms, J. D. (2003). Student engagement at school. A sense of belonging and participation. Results from PISA 2000. OECD.

Wu, J.-Y., Hughes, J. N., \& Kwok, O.-M. (2010). Teacher-student relationship quality type in elementary grades: Effects on trajectories for achievement and engagement. Journal of School Psychology, 48, 357-387. https://doi.org/10.1016/j.jsp.2010.06.004

You, S. (2011). Peer influence and adolescents' school engagement. Procedia-Social and Behavioural Sciences, 29, 829-835.

Yuksel, M., \& Geban, Ö. (2016). Examination of science and math course achievements of vocational high school students in the scope of self-efficacy and anxiety. Journal of Education and Training Studies, 1(4), 88-100.

Yunus, M. M., Osman, W. S. W., \& Ishak, N. M. (2011). Teacher-student relationship factor affecting motivation and academic achievement in ESL classroom. Procedia Social and Behavioral Sciences, $15,2637-2641$.

Zee, M., Koomen, H. M. Y., \& Van der Veen, I. (2013). Student-teacher relationship quality and academic adjustment in upper elementary school: The role of student personality. Journal of School Psychology, 51, 517-533. https://doi.org/10.1016/j.jsp.2013.05.003

Zimmer-Gembeck, M. J., Chipuer, H. M., Hanish, M., Creed, P. A., \& McGregor, L. (2006). Relationship at school and stage-environment fit as resources for adolescent engagement and achievement. Journal of Adolescence, 29, 911-933. https://doi.org/10.1016/j.adolescence.2006.04.008

Publisher's Note Springer Nature remains neutral with regard to jurisdictional claims in published maps and institutional affiliations.

Marina Palmgren MA is a doctoral student in the program of School, Education and Society (SEDUCE), of the Faculty of Educational Sciences, in the University of Helsinki, Finland. Her research interests are in the field of educational psychology, including issues of belonging and inclusion, and pupils learning and well-being in the context of school development. Among her recent publications is: Palmgren, M., Pyhältö, K., Soini, T., \& Pietarinen, J. (2017). Students' Engaging School Experiences: A Precondition for Functional Inclusive Practice. International Journal of Whole Schooling, Special Issue, 26-49. She is also working full-time as a special teacher.

Kirsi Pyhältö PhD. is professor of higher education, at the Center of University Teaching and Learning (HYPE), and director of HYMY - doctoral school at the University of Helsinki She is also extraordinary professor, University of Stellenbosch, South-Africa. Her interest focuses on teacher and student learning and well-being and researcher education and early career researchers. She has over 200 research publications.

Janne Pietarinen PhD. is full-Professor of Educational Sciences, School of Applied Educational Science and Teacher Education, University of Eastern Finland. Pietarinen works as Dean of Philosophical Faculty at the University of Eastern Finland, and Adjunct Professor at the Tampere University. His research interests are in educational transitions, pupil and teacher learning, and well-being in the context of sustainable school development.

Jenni Sullanmaa $\mathrm{PhD}$. is a postdoctoral researcher in the Faculty of Education and Culture, Tampere University. Her research interests include school development and teachers' professional agency.

Tiina Soini PhD. is Research Director, in the Faculty of Education and Culture, Tampere University and adjunct professor in Philosophical Faculty, University of Eastern Finland. Her research interests include, educational reforms, school development, teachers'professional agency and well-being, and pupils'learning agency. 


\section{Authors and Affiliations}

\section{Marina Palmgren ${ }^{1}$ (D) Kirsi Pyhältö 2,3,4 Janne Pietarinen $^{5} \cdot$ Jenni Sullanmaa $^{5,2}$. Tiina Soini $^{6}$}

Kirsi Pyhältö

kirsi.pyhalto@helsinki.fi

Janne Pietarinen

janne.pietarinen@uef.fi

Jenni Sullanmaa

jenni.sullanmaa@helsinki.fi

Tiina Soini

tiina.soini@utu.fi

1 Doctoral Program of School, Education and Society (SEDUCE), Faculty of Educational Sciences, University of Helsinki, Siltavuorenpenger 5A, 00014 Helsinki, Finland

2 Centre for University Teaching and Learning, Faculty of Educational Sciences, University of Helsinki, Helsinki, Finland

3 Faculty of Educational Sciences, University of Oulu, Oulu, Finland

4 University of Stellenbosch, Stellenbosch, South Africa

5 School of Applied Educational Science and Teacher Education, University of Eastern Finland, Kuopio, Finland

6 Department of Teacher Education, University of Tampere, Tampere, Finland 